\title{
The medicinal flora of Majouri-Kirchi forests (Jammu and Kashmir State), India
}

\author{
S.K. Kapur ${ }^{\text {a }}$, A.K. Shahi ${ }^{a}$, Y.K. Sarin ${ }^{a}$ and Daniel E. Moerman ${ }^{b}$ \\ ${ }^{a}$ Regional Research Laboratory, Canal Road, Jammu Tawi 180001 (India) and ${ }^{b}$ Department of Behavioral Sciences, University of \\ Michigan-Dearborn, Dearborn, MI (U.S.A.)
}

(Received September 20, 1991; revision received October 21, 1991; accepted October 22, 1991)

\section{Introduction}

The Udhampur district lies in the northernmost portion of India, approximately at $75^{\circ} 7^{\prime}$ to $75^{\circ}$ $10^{\prime}$ longitude east and $33^{\circ} 54^{\prime}$ to $33^{\circ} 57^{\prime}$ latitude north in the State of Jammu and Kashmir. The total area of the district is $2549 \mathrm{~km}^{2}$; it has a hilly topography ranging from $300 \mathrm{~m}$ to $2780 \mathrm{~m}$ above sea level. The region consists of limestone, quartzites, grit and earthy clay. The soil is sandy except in ravines and densely forested areas. The tract is extremely hilly, arduous and rugged. The flora of the district has recently been described by Swami and Gupta (1988a,b, 1989a,b) while the economically useful plants of the region have been described by Kapur $(1990 a, b)$.

\section{Methodology}

The sources listed above provide the data shown in Table 1. The plants have been arranged in families according to the Bentham and Hooker system of classification; the nomenclature has been adjusted to take into account the most recent work in the area (Cope, 1982; Kumar and Subramanium, 1986; Bennet, 1987). Using the method of regression and residual analysis developed by Moerman (1991), we carried out a regression analysis of the number of medicinal species per family (MS) on the total number of species

\footnotetext{
Correspondence to: Daniel E. Moerman, Department of Behavioral Sciences, University of Michigan-Dearborn, Dearborn MI 48128, U.S.A.
}

in each family (TS) for the 106 flowering plant families in the region. The regression equation is

MS $=0.72+0.53 *$ TS

According to this equation and under the null hypothesis (essentially saying that the selection of medicinal plants is random) the number of medicinal species per family should be equal to the total number of species in the family times 0.53 plus 0.72 . These predicted values are shown in Table 1. Subtracting the predicted value from the actual value gives us the residual value for each data point. The residuals are also shown in Table 1; the families are shown in order of the decreasing value of these residuals. The table is organized in the same manner as is Appendix A in Moerman's paper on North American medicinal plants (1991, pp. 33-37) and may be compared to it. The data are shown in Fig. 1 where the residual may be visualized as the vertical distance from the data point to the regression line.

\section{Discussion}

Residuals range from 19.6 to -18.3 . Families with large positive residuals are ones used more often than chance would allow, while families with large negative values are used less than chance would allow. Among families with a larger than expected number of medicinals are Asteraceae, Euphorbiaceae, Ranunculaceae and Lamiaceae. Among the low use families are Poaceae, Papilionaceae, Urticaceae, Anacardiaceae and Brassicaceae. 
TABLE

REGRESSION ANALYSIS OF 106 JAMMU AND KASHMIR PLANT FAMILIES

Rank Family
species species dicted dual (TS) (MS)

\begin{tabular}{|c|c|c|c|c|c|}
\hline 1 & Asteraceae & 64 & 54 & 34.4 & 19.6 \\
\hline 2 & Euphorbiaceae & 19 & 17 & 10.7 & 6.3 \\
\hline 3 & Ranunculaceae & 22 & 18 & 12.3 & 5.7 \\
\hline 4 & Lamiaceae & 37 & 25 & 20.2 & 4.8 \\
\hline 5 & Liliaceae & 9 & 9 & 5.5 & 3.5 \\
\hline 6 & Solanaceae & 11 & 10 & 6.5 & 3.5 \\
\hline 7 & Amaranthaceae & 13 & 11 & 7.6 & 3.4 \\
\hline 8 & Polygonaceae & 16 & 12 & 9.2 & 2.8 \\
\hline 9 & Moraceae & 7 & 7 & 4.4 & 2.6 \\
\hline 10 & Mimosaceae & 6 & 6 & 3.9 & 2.1 \\
\hline 11 & Rubiaceae & 16 & 11 & 9.2 & 1.8 \\
\hline 12 & Apiaceae & 18 & 12 & 10.2 & 1.8 \\
\hline 13 & Caesalpiniaceae & 7 & 6 & 4.4 & 1.6 \\
\hline 14 & Rhamnaceae & 7 & 6 & 4.4 & 1.6 \\
\hline 15 & Malvaceae & 9 & 7 & 5.5 & 1.5 \\
\hline 16 & Acanthaceae & 17 & 11 & 9.7 & 1.3 \\
\hline 17 & Scrophulariaceae & 19 & 12 & 10.7 & 1.3 \\
\hline 18 & Menispermaceae & 3 & 3 & 2.3 & 0.7 \\
\hline 19 & Zingiberaceae & 3 & 3 & 2.3 & 0.7 \\
\hline 20 & Orchidaceae & 3 & 3 & 2.3 & 0.7 \\
\hline 21 & Hypericaceae & 3 & 3 & 2.3 & 0.7 \\
\hline 22 & Meliaceae & 3 & 3 & 2.3 & 0.7 \\
\hline 23 & Geraniaceae & 5 & 4 & 3.4 & 0.6 \\
\hline 24 & Caryophyllaceae & 7 & 5 & 4.4 & 0.6 \\
\hline 25 & Asclepiadaceae & 7 & 5 & 4.4 & 0.6 \\
\hline 26 & Nyctaginaceae & 2 & 2 & 1.8 & 0.2 \\
\hline 27 & Crassulaceae & 2 & 2 & 1.8 & 0.2 \\
\hline 28 & Lythraceae & 2 & 2 & 1.8 & 0.2 \\
\hline 29 & Aceraceae & 2 & 2 & 1.8 & 0.2 \\
\hline 30 & Dioscoreaceae & 2 & 2 & 1.8 & 0.2 \\
\hline 31 & Loganiaceae & 2 & 2 & 1.8 & 0.2 \\
\hline 32 & Onagraceae & 2 & 2 & 1.8 & 0.2 \\
\hline 33 & Philadelphaceae & 2 & 2 & 1.8 & 0.2 \\
\hline 34 & Saxifragaceae & 2 & 2 & 1.8 & 0.2 \\
\hline 35 & Balsaminaceae & 2 & 2 & 1.8 & 0.2 \\
\hline 36 & Aquifoliaceae & 2 & 2 & 1.8 & 0.2 \\
\hline 37 & Violaceae & 2 & 2 & 1.8 & 0.2 \\
\hline 38 & Rosaceae & 23 & 13 & 12.8 & 0.2 \\
\hline 39 & Rutaceae & 6 & 4 & 3.9 & 0.1 \\
\hline 40 & Leeaceae & 1 & 1 & 1.2 & -0.2 \\
\hline 41 & Smilacaceae & 1 & 1 & 1.2 & -0.2 \\
\hline 42 & Parnassiaceae & 1 & 1 & 1.2 & -0.2 \\
\hline 43 & Zygophyllaceae & 1 & 1 & 1.2 & -0.2 \\
\hline 44 & Iridaceae & 1 & 1 & 1.2 & -0.2 \\
\hline 45 & Papaveraceae & 1 & 1 & 1.2 & -0.2 \\
\hline 46 & Martyniaceae & 1 & 1 & 1.2 & -0.2 \\
\hline 47 & Punicaceae & 1 & 1 & 1.2 & -0.2 \\
\hline 48 & Portulacaceae & 1 & 1 & 1.2 & -0.2 \\
\hline 49 & Morinaceae & 1 & 1 & 1.2 & -0.2 \\
\hline 50 & Plumbaginaceae & 1 & 1 & 1.2 & -0.2 \\
\hline 51 & Podophyllaceae & 1 & 1 & 1.2 & -0.2 \\
\hline 52 & Cuscutaceae & 1 & 1 & 1.2 & -0.2 \\
\hline 53 & Buxaceae & 1 & 1 & 1.2 & -0.2 \\
\hline 54 & Bombacaceae & 1 & 1 & 1.2 & -0.2 \\
\hline 55 & Droseraceae & 1 & 1 & 1.2 & -0.2 \\
\hline 56 & Bignoniaceae & 1 & 1 & 1.2 & -0.2 \\
\hline
\end{tabular}

TABLE 1 (continued)

\begin{tabular}{lllll}
\hline Rank Family & Total & Medicinal & Pre- & Resi- \\
& & &
\end{tabular}

(TS) (MS)

\begin{tabular}{|c|c|c|c|c|c|}
\hline 57 & Campanulaceae & 1 & 1 & 1.2 & -0.2 \\
\hline 58 & Cannabaceae & 1 & 1 & 1.2 & -0.2 \\
\hline 59 & Commelinaceae & 1 & 1 & 1.2 & -0.2 \\
\hline 60 & Cornaceae & 1 & 1 & 1.2 & -0.2 \\
\hline 61 & Cactaceae & $\hat{1}$ & 1 & 1.2 & -0.2 \\
\hline 62 & Araliaccae & 1 & I & 1.2 & -0.2 \\
\hline 63 & Arecaceae & 1 & 1 & 1.2 & -0.2 \\
\hline 64 & Hippocastanaceae & 1 & 1 & 1.2 & -0.2 \\
\hline 65 & Haemodoraceae & 1 & I & 1.2 & -0.2 \\
\hline 66 & Ericaceae & 1 & 1 & 1.2 & -0.2 \\
\hline 67 & Begoniaceae & 1 & 1 & 1.2 & -0.2 \\
\hline 68 & Plantaginaceae & 3 & 2 & 2.3 & -0.3 \\
\hline 69 & Lauraceae & 3 & 2 & 2.3 & -0.3 \\
\hline 70 & Chenopodiaceae & 3 & 2 & 2.3 & -0.3 \\
\hline 71 & Myrsinaceae & 3 & 2 & 2.3 & -0.3 \\
\hline 72 & Flacourtiaceae & 3 & 2 & 2.3 & -0.3 \\
\hline 73 & Polygalaceac & 3 & 2 & 2.3 & -0.3 \\
\hline 74 & Valerianaceae & 3 & 2 & 2.3 & -0.3 \\
\hline 75 & Oxalidaceae & 5 & 3 & 3.4 & -0.4 \\
\hline 76 & Apocynaceae & 7 & 4 & 4.4 & -0.4 \\
\hline 77 & Primulaceae & 7 & 4 & 4.4 & -0.4 \\
\hline 78 & Oleaceae & 9 & 5 & 5.5 & -0.5 \\
\hline 79 & Berberidaceae & 2 & 1 & 1.8 & -0.8 \\
\hline 80 & Salicaceae & 2 & 1 & 1.8 & -0.8 \\
\hline 81 & Linaceae & 2 & 1 & 1.8 & -0.8 \\
\hline 82 & Loranthaceae & 2 & 1 & 1.8 & -0.8 \\
\hline 83 & Dipsacaceae & 2 & 1 & 1.8 & -0.8 \\
\hline 84 & Fagaccac & 2 & 1 & 1.8 & -0.8 \\
\hline 85 & Elaeagnaceae & 2 & 1 & 1.8 & -0.8 \\
\hline 86 & Celastraceae & 2 & 1 & 1.8 & -0.8 \\
\hline 87 & Thymelaeaceae & 4 & 2 & 2.8 & -0.8 \\
\hline 88 & Tiliaceae & 6 & 3 & 3.9 & -0.9 \\
\hline 89 & Caprifoliaceae & 8 & 4 & 4.9 & -0.9 \\
\hline 90 & Convolvulaceae & 12 & 6 & 7.0 & -1.0 \\
\hline 91 & Ulmaceae & 3 & 1 & 2.3 & -1.3 \\
\hline 92 & Ehretiaceae & 3 & 1 & 2.3 & -1.3 \\
\hline 93 & Fumariaceae & 3 & 1 & 2.3 & -1.3 \\
\hline 94 & Combretaceae & 3 & 1 & 2.3 & -1.3 \\
\hline 95 & Araccae & 5 & 2 & 3.4 & -1.4 \\
\hline 96 & Boraginaceae & 9 & 4 & 5.5 & -1.5 \\
\hline 97 & Verbenaceae & 11 & 5 & 6.5 & -1.5 \\
\hline 98 & Gentianaceae & 4 & 1 & 2.8 & -1.8 \\
\hline 99 & Sapindaceae & 4 & 1 & 2.8 & -1.8 \\
\hline 100 & Cyperaceae & 11 & 4 & 6.5 & -2.5 \\
\hline 101 & Cucurbitaceae & 8 & 2 & 4.9 & -2.9 \\
\hline 102 & Brassicaceae & 16 & 6 & 9.2 & -3.2 \\
\hline 103 & Anacardiaceae & 9 & 2 & 5.5 & -3.5 \\
\hline 104 & Urticaceae & 8 & 1 & 4.9 & -3.9 \\
\hline 105 & Papilionaceae & 56 & 25 & 30.2 & -5.2 \\
\hline 106 & Poaceae & 79 & 24 & 42.3 & -18.3 \\
\hline
\end{tabular}

These are all relatively large families. One might say, therefore, that this sort of analysis obscures the contributions of small families. But small families produce relatively few medicines; while 


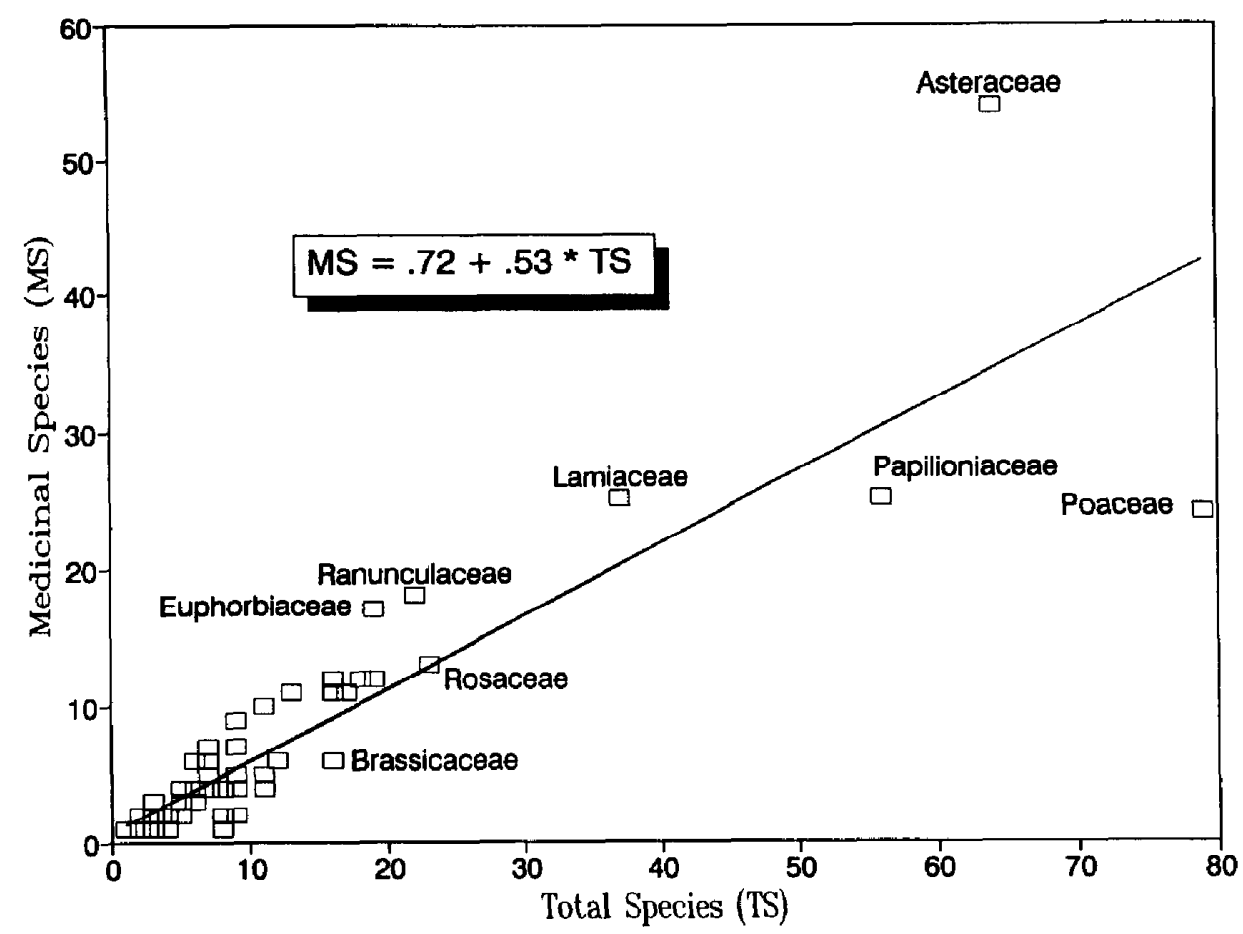

Fig. 1. Regression plot for 106 plant families in the Majouri-Kirchi forest tract in Jammu and Kashmir showing medicinal species vs. total species. The points plotted are the actual values of the number of species and medicinal species in each family. The residual value is represented by the vertical distance from the point to the regression line. Residuals above the line are positive while those below the line are negative. Several of the families discussed in the text are labeled.

the larger 53 Indian families have 656 species of which $\mathbf{4 0 0}$ are medicinal, the smaller 53 have only 83 of which 66 are medicinal. (By way of comparison, in North America, the larger 116 families have 15,851 species of which 2023 are medicinal, while the smaller 116 have only 419 species of which 72 are medicinal.) Alternatively, then, one may say that this method reveals the respective contributions of the larger families, and, in particular, allows us to differentiate those large families which produce many medicines (e.g., Asteraceae) from those which produce few (e.g., Poaceae). This is not to say that the medicinal species found in small families are not 'interesting,' only that those families are not substantial producers of traditional medicines. One could compare families of intermediate size, or small ones, in the same manner.

There are several points of difference between the medicinal floras of Jammu and Kashmir and of North America. Not surprisingly, the flora of North America is a good deal larger than the flora of this small region in India. There are 232 families in North America, 106 here. There are well over 16,000 species in North America, while there are only 739 in the Majouri-Kirchi forests. In North America, some $13 \%$ of the flora has been used medicinally by Native Americans (21.44 of 16,270 species); in Jammu and Kashmir, nearly $64 \%$ are so used (466 of 731). In North America, many families (over 90) produce no species used medicinally; in Jammu and Kashmir each of the 106 families produces at least one medicinally used species.

Given these differences, the following similarities seem quite striking. Four families appear on the 'top 10' lists of high-use families in both areas: Asteraceae (first on both), Ranunculaceae, Lamiaceae and Liliaceae. Solanaceae ranks 6th in Jammu and Kashmir and 13th in North America. These families have many species used medicinally on both sides of the world. Two families occur on both 'bottom 10' lists: Poaceae (last on both) and Cyperaceae. Poaceae, which only rarely produces biologically active defensive chemicals, is the primary source of human staple foods.

A few notable differences occur in the placement of families on these lists. Rosaceae, a highly favored source of medicines in North America 
(second on the list, with 115 of a total 577 species used medicinally), is well down the list in Jammu and Kashmir in 37th place; even so, 13 of its 23 species are used medicinally. Most striking perhaps is the different placement of Euphorbiaceae which is second in Jammu and Kashmir (with 17 of its 19 species used medicinally) and very near the bottom of the list in North America, in position 222 (with only 23 of its 264 species used medicinally).

There is a similar situation with the pulses which is a bit more complex since there are some differences in the classifications used with the data reported here and the data reported by Moerman. The North American data for the pulses are combined into the family Fabaceae, which includes three subfamilies, the Mimosoideae, the Caesalpinioideae and the Papilionoideae. These three North American subfamilies are reported as three families in the Indian data. Combining them for the purpose of comparison yields a group with 69 total species and 37 medicinal species. Applying the regression equation, this would give a predicted number of medicinal species of 37.3 with a residual of 0.3 ; this 'family' would be ranked 26 th on Table 1, very much in the middle. By contrast, the Fabaceae family in North America is third from the bottom of the list with only 108 of its 1225 species used medicinally. This family is apparently much more likely to be a source of medicines in India than in North America.

Among important North American medicinal families which do not occur at all in the Majouri Kirchi forests of Jammu and Kashmir State is Corylaceae.

\section{Conclusions}

This simple method of comparison allows us to identify (a) plant families which are apparently substantial sources of traditional medicines worldwide (such as Asteraceae), (b) families with varying medicinal usage in different places (such as Euphorbiaceae and Fabaceae), (c) families which are apparently never substantial sources of traditional medicines (such as Poaceae). These comparisons can easily be extended to other areas with extensive botanical and ethnobotanical information.

\section{References}

Bennet, S.S.R. (1987) Name Changes in Flowering Plants of India and Adjoining Regions. Triseas Publishers, Dehradun.

Cope, T. (1982) Poaceae. In: E. Nasir and S.I. Ali (Eds.), Flora of Pakistan. Karachi.

Kapur, S.K. (1990a) Economically useful plants of MajouriKirchi forest tract (Jammu and Kashmir) I. Ranunculaceae to Acanthaceae. Journal of Economic and Taxonomic Botany $14,501-522$.

Kapur, S.K. (1990b) Economically useful plants of MajouriKirchi forest tract (Jammu and Kashmir) II. Verbenaceae to Bombusaceae \& Gymnosperms. Journal of Economic and Taxonomic Botany 14, 523-534.

Kumar, V. and Subramanium, B. (1986) Chromosome Atlas of Flowering Plants of the Indian Sub-continem, Vol. I. Botanical Survey of India, Calcutta.

Moerman, D.E. (1991) The medicinal flora of native North America: An analysis. Journal of Ethnopharmacology 31, $1-42$.

Swami, A. and Gupta, B.K. (1988a) Plants of Udhampur District (Jammu and Kashmir). A preliminary list. Part I. Indian Journal of Forestry 11, 150-157.

Swami, A. and Gupta, B.K. (1988b) Plants of Udhampur District (Jammu and Kashmir). A preliminary list. Part II. Indian Journal of Forestry 11, 244-249.

Swami, A. and Gupta, B.K. (1989a) Plants of Udhampur District (Jammu and Kashmir). Part III. Supplementary list. Indian Journal of Forestry 12, 73-75.

Swami, A. and Gupta, B.K. (1989b) Plants of Udhampur District (Jammu and Kashmir). Part IV. Some more additions. Indian Journal of Forestry 12, 326-327. 